\title{
Gambaran Tingkat Pengetahuan Remaja Putri Usia 10-19 Tahun Tentang Personal Hygiene Saat Menstruasi Di Rt 15 Sumberejo Kemiling Bandar Lampung
}

\author{
Dimas Ning Pangesti ${ }^{1}$, Praty Milindasari ${ }^{2}$, \\ Dimas NingPangesti : AkademiKeperawatanBaitulHikmah Bandar Lampung \\ Praty Milindasari : Akademi Keperawatan Bunda Delima Bandar Lampung \\ E-mail :dimasningpangesti@gmail.com
}

\begin{abstract}
Abstrak
Pengetahuan merupakan hasil tahu dan ini terjadi setelah orang melakukan penginderaan terhadap suatu objek tertentu. Menstruasi adalah proses alamiah yang terjadi pada perempuan. Menstruasi merupakan perdarahan teratur dari uterus sebagai tanda bahwa organ kandungan telah berfungsi matang. Kebersihan perorangan adalah suatu tindakan yang dilakukan untuk memelihara kebersihan dan kesehatan seseorang untuk kesejahteraan fisik dan psikis. Mengidentifikasi tingkat pengetahuan remaja putri usia 10-19 tahun tentang personal hygiene saat menstruasi. Desain penelitian yang digunakan adalah deskriptif. Responden yang digunakan pada peneitian ini sebanyak 30 responden. Sampling yang digunakan yaitu accidentalsampling,. Hasil penelitian yang dilakukan pada 30 responden menunjukkan tingkat pengetahuan remaja usia 10-19 tahun tentang personal hygiene di RT 15 didapatkan hasil tingkat pengetahuan baik pada remaja sebanyak 12 (40\%) responden, tingkat pengetahuan cukup sebanyak 15 (50\%) responden, dan tingkat pengetahuan kurang sebanyak $3(10 \%)$ responden. Rata-rata tingkat pengetahuan baik pada remaja sebanyak $12(40 \%)$ yaitu dari pendidikan SMA, tingkat pengetahuan cukup sebanyak 15 (50\%) yaitu pendidikan SMA 3 responden, SMP sejumlah 7 responden dan SD sejumlah 5 responden. Tingkat pengetahuan kurang sejumlah 3 (10\%) pendidikan SD. Kesimpulan dari karakteristik responden berdasarkan usia 10-19 tahun, rata-rata responden yaitu berusia 14-19 tahun sejumlah $22(73 \%)$. Rata-rata pendidikan responden yaitu SMA 15\%. Rata-rata pekerjaan orang tua responden yaitu wiraswasta sejumah $15(50 \%)$. Saran dalam penelitian ini adalah Meningkatkan tingkat pengetahuan remaja tentang personal hygiene saat menstruasi, perlu dilakukan pembinaan kepada penduduk desa secara terus menerus, melalui penyuluhan oleh petugas kesehatan dengan cara penjelasan yang berisi pesan tentang personal hygiene saat menstruasi.
\end{abstract}

Kata kunci : Tingkat pengetahuan, Remaja, Personal hygiene, Menstruasi

\begin{abstract}
Knowledge is the result of knowing and this occurs after people have sensed a certain object. Menstruation is a natural process that occurs in women. Menstruation is regular bleeding from the uterus as a sign that the uterine organs have matured. Personal hygiene is an action taken to maintain the cleanliness and health of a person for physical and psychological well-being. Identifying the level of knowledge of adolescent girls aged 10-19 years about personal hygiene during menstruation. The research design used is descriptive. The respondents used in this study were 30 respondents. The sampling used was accidental sampling. The results of research conducted on 30 respondents showed the level of knowledge of adolescents aged 10-19 years about personal hygiene in RT 15, the results showed that the level of knowledge was good in adolescents as many as 12 (40\%) respondents, the level of knowledge was sufficient as many as 15 (50\%) respondents, and the level of knowledge was sufficient for $15(50 \%)$ respondents. lack of knowledge as many as 3 (10\%) respondents. The average level of good knowledge in adolescents is 12 (40\%) namely from high school education, sufficient knowledge level is 15 (50\%), namely high school education 3 respondents, junior high school 7 respondents and elementary school 5 respondents. The level of knowledge is less than 3 (10\%) elementary education. The conclusion from the characteristics of respondents based on the age of 10-19 years, the average number of respondents aged 14-19 years was 22 (73\%). The average education of the respondents is SMA 15\%. The average occupation of the respondent's parents is $15(50 \%)$ self-employed. Suggestions in this study are to increase the level of knowledge of adolescents about personal hygiene during menstruation, it is necessary to provide continuous guidance to villagers, through counseling by health workers by way of explanations containing messages about personal hygiene during menstruation
\end{abstract}

Keywords $\quad$ : Knowledge level, Adolescents, Personal hygiene, Menstruation 


\section{PENDAHULUAN}

Masa remaja adalah individu yang berusia antara 11-12 tahun sampai 20-21 tahun, ditandai oleh ciri perubahan pada penampilan fisik dan fungsi fisiologis, terutama yang terkait dengan kelenjar seksual. Remaja merupakan masa dimana individu mengalami perubahan-perubahan dalam aspek kognitif, emosi, sosial, dan moral, diantara masa anakanak menuju masa dewasa (Kusmiran, 2012).

Menstruasi adalah proses alamiah yang terjadi pada perempuan. Menstruasi merupakan perdarahan teratur dari uterus sebagai tanda bahwa organ kandungan telah berfungsi matang. Umumnya, remaja yang mengalami pertama kali menstruasi (menarche) adalah pada usia 12 sampai 16 tahun (Kusmiran, 2012).

Angka kejadian akibat infeksi alat reproduki di perkirakan sekitar 2,3 juta pertahun 1,2 juta diantaranya ditemukan di Negara berkembang sedangkan jumlah penderita baru sekitar 5 juta pertahun dan terdapat di Negara berkembang sekitar 3 juta (Berman, 2009 dalam Agra 2016). Angka kejadian infeksi pada organ reproduksi diperkirakan 15 dari 20 remaja putri pernah mengalami keputihan setiap tahunnya. Infeksi tersebut disebabkan karena kurangnya kebersihan diri, terutama vulva hygiene saat menstruasi. Data penelitian tentang kesehatan reproduksi wanita menunjukkan bahwa $75 \%$ wanita indonesia pernah mengalami infeksi berupa keputihan abnormal dan satu kali serangan infeksi jamur pada vagina wanita World Health Organization (WHO, 2012).

Data di Indonesia, data pasti tentang jumlah penderita Infeksi Saluran Reproduksi (ISR) dan Isfeksi Menular Seks (IMS) tidak mudah didapat. Penderita Isfeksi Menular Seks (IMS) kebanyakan berusia 15-24 tahun. Jumlah wanita di dunia yang pernah mengalami keputihan sekitar $75 \%$ sedangkan wanita eropa yang mengalami keputihan sebesar $25 \%$ dan berdasarkan dari data kependudukan dan keluarga berencana (BKKBN) untuk wanita indonesia yang mengalami keputihan sekitar 75\%. Bakterial vaginosis (BV) adalah penyebab tersering keputihan patologis (45\%-50\% kasus infeksi vagina) (Endang,2007 dalam Agra,2016).

Hasil presurvey yang penulis lakukan pada tanggal 3 februari 2021 di RT 15 Sumberejo kemiling, Bandar Lampung dari 43 remaja didapatkan 43 remaja $(100 \%)$ sudah menstruasi. Dari 30 remaja yang sudah menstruasi 18 remaja (60\%) mengalami gatal gatal pada daerah vagina saat menstruasi, 8 remaja $(26,7 \%)$ mengalami masalah sering keputih dan 4 remaja $(13,3 \%)$ mengalami 
menstruasi tidak teratur. Semua remaja yaitu 30 remaja (100\%) mengganti pembalut yaitu saat pembalutnya sudah penuh. Semua remaja di RT 15 (100\%) belum pernah mengikuti seminar atau penyuluhan tentang personal hygiene saat menstruasi.

Personal hygiene berasal dari bahasa yunani yang berarti personal yang artinya perorangan dan hygiene berarti sehat. Kebersihan perorangan adalah suatu tindakan yang dilakukan untuk memelihara kebersihan dan kesehatan seseorang untuk kesejahteraan fisik dan psikis (Tarwono dan Wartonah, 2004 dalam Yuni, 2015). Hygiene pada saat menstruasi merupakan komponen personal hygiene (kebersihan perorangan) yang memegang peran penting dalam status perilaku kesehatan seseorang, termasuk menghindari adanya gangguan pada fungsi alat reproduksi (Yuni, 2015). Dampak personal hygiene yang tidak baik yaitu : Demam, Radang pada permukaan vagina, Gatal-gatal pada kulit vagina,Keputihan, Rasa panas atau sakit pada bagian bawah perut, Gangguan integritas kulit, Infeksi saluran reproduksi (Yuni 2015).

\section{METODOLOGI}

Desainpenelitian adalah sesuatu yang sangat penting dalam penelitian yang mana dapatdipergunakan sebagai alat untuk mengontrol atau mengendalikan beberapadesain penelitian yang digunakan adalah deskriptif. Penelitian deskriptif merupakan Penelitian deskriptif merupakan penelitian yang bertujuan untuk mendeskripsikan atau memaparkan peristiwaperistiwa penting yang terjadi pada masa kini. (Nursalam, 2016).

Populasi dalam penelitian adalah subjek yang memenuhi kriteriayang telah ditetapkan (Nursalam, 2016). Populasi dalam remaja putri usia 10-19 tahun di wilayah RT 15 Sumberejo Kemiling Bandar Lampung berjumlah 43 orang.

Sampel merupakan sebagian atau perwakilan dari populasi yangditeliti. Sampel menjadi bagian dari jumlah populasi yang diteliti.Sehingga hasil penelitian bisa digeneralisasikan (Hamdi \&Bahruddin, 2014).Sampel dalam karya tulis ilmiah iniyaitu remaja putri di wilayah RT 15 Sumberejo Kemiling Bandar lampung berjumlah 30 orang.

Nursalam (2016), sampling adalah proses menyeleksi porsi dari populasi yang dapat mewakilipopulasi yang ada. Teknik sampling yang digunakan dalam proposal karya tulisilmiah ini menggunakan accidental sampling.

Instrumen yang digunakan dalam penelitian ini adalah surat izin karya tulis, lembar informed consent, lembar kuesioner dengan 
jumlah soal 20 soal, alat pelindung diri (masker dan handsinitizer), alat tulis, format evaluasi.

Proses pengumpulan data adalah tahap persiapan yaitu peneliti dan responden menyiapkan alat pelindung diri (masker dan hansinitizer) dan mencuci tangan,mengurus perizinan antara institusi dengan ketua RT di RT 15 Sumberejo Kemiling Bandar Lampung, menjelaskan maksud, tujuan, dan waktu karya tulis ilmiah pada RT 15 yang bertanggung jawab di tempat dan meminta persetujuan melibatkan subjek dalam kegiatan ini,melakukan pengumpulan data melalui wawancara kepada ketua RT 15 tentang hal yang berkaitan dengan data remaja di RT 15, melakukan pengumpulan data melalui wawancara kepada responden tentang hal yang berkaitan dengan data pribadi dilengkapi dengan data RT 15, mempersiapkan responden sesuai kriteria yang dibutuhkan. Tahap pelaksanaan yaitu peneliti dan responden menggunakan alat pelindung diri (masker dan hansinitizer) dan mencuci tangan, menjelaskan maksud dan tujuan karya tulis ilmiah pada responden untuk mengisi lembar informed consent sebagai bukti persetujuan menjadi subjek peneliti, peneliti menjelaskan cara pengisian kuesioner pada responden, meminta responden untuk mengisi kuesioner sejumlah 20 soal dengan jawaban benar atau salah dalam waktu 15-20 menit ,melakukan penelitian dan pengolahan data selama 5 hari dan menyajikan hasil pelaporan data dalam bentuk narasi atau deskriptif.Cara pengolahan data dari karya tulis ilmiah ini adalah Editing, Coding, Scorin, Entry

Analisa data karya tulis ilmiah menggunakan analisis deskriptif yaitu analisa data dilakukan dengan cara score, dimana remaja memilih setiap jawaban dari pertanyaan yang menurutnya "BENAR" dan "SALAH".Hasil dari jawaban remaja yang telah diberikan pembobotan dijumlahkan dan dibandingkan dengan score yang diharapkan lalu dikalikan 100\%. Hasil yang dihitung adalah jawaban yang "SEBENARNYA", bukan yang jawaban dengan kata "BENAR".Presentasi rata-rata menunjukan Gambaran tingkat pengetahuan remaja putriusia 10-19 tahun tentang personal hygiene saat menstruasi di RT 15 Sumberejo Kemiling Bandar Lampung Tahun 2021.

Etika yang digunakan dalam penelitian ini adalah Informed consent (persetujuan menjadi klien), Informed consent (persetujuan menjadi klien), Confidentiality (kerahasiaan), Respect for justice and inclusivennes (keadilan dan inklusivitas/ keterbukaan)

\section{HASIL}

\section{Hasil gambaran tingkat penegtahuan responden}

Tabel 1.Distribusi frekuensi responden berdasarkan hasil gambaran 
tingkatpengetahuan responden di RT 15 Sumberejo Kemiling Bandar Lampung Tahun 2021.

\begin{tabular}{ccccc}
\hline NO & $\begin{array}{c}\text { Hasil } \\
\text { gambaran } \\
\text { tingkat } \\
\text { pengetahu } \\
\text { an }\end{array}$ & $\begin{array}{c}\text { Rentang } \\
\text { pengetah } \\
\text { uan }\end{array}$ & $\begin{array}{c}\text { Frekue } \\
\text { nsi }(\boldsymbol{f})\end{array}$ & $\begin{array}{c}\text { Prese } \\
\text { ntase } \\
(\%)\end{array}$ \\
\hline $\mathbf{1}$ & Baik & $80-90 \%$ & 12 & 40 \\
$\mathbf{2}$ & cukup & $60-75 \%$ & 15 & 50 \\
$\mathbf{3}$ & kurang & $55 \%$ & 3 & 10 \\
\hline & Jumlah & & $\mathbf{3 0}$ & $\mathbf{1 0 0}$ \\
\hline
\end{tabular}

Bedasarkan tabel 1 di atas dapat dilihat bahwa dari 30 responden menunjukkan tingkat pengetahuan remaja usia 10-19 tahun tentang personal hygiene di RT 15 didapatkan hasil tingkat pengetahuan baik pada remaja sebanyak $12(40 \%)$ responden dengan rentang pengetahuan 80-90\%, tingkat pengetahuan cukup sebanyak 15 (50\%) responden dengan rentang pengetahuan 60$75 \%$, dan tingkat pengetahuan kurang sebanyak 3 (10\%) responden dengan rentang pengetahuan $55 \%$.

\section{Faktor yang mempengaruhi tingkat pengetahuan responden}

Hasil penelitian mendapatkan faktor yang mempengaruhi tingkat pengetahuan berdasarkan usia, pendidikan, ekonomi, sosial budaya, media massa/informasi.

Tabel 2. Distribusi frekuensi responden berdasarkan usia remaja di RT 15 Sumberejo Kemiling Bandar lampung Tahun 2021

\begin{tabular}{cccc}
\hline NO & Jenis usia & Frekuensi $(\boldsymbol{f})$ & $\begin{array}{c}\text { Persentase } \\
(\%)\end{array}$ \\
\hline 1 & $10-13$ tahun & 8 & 27 \\
2 & $14-19$ tahun & 22 & 73 \\
\hline & Jumlah & $\mathbf{3 0}$ & $\mathbf{1 0 0}$ \\
\hline
\end{tabular}

Berdasarkan tabel 2 diatas dapat dilihat bahwa dari 30 responden terdapat usia 10-13 tahun sejumlah 8 orang $(27 \%)$, responden yang berusia 14-19 tahun terdapat 22 orang $(73 \%)$.

Tabel3. Distribusi frekuensi responden berdasarkan pendidikan di remaja di RT 15 Sumberejo Kemiling Bandar Lampung Tahun 2021

\begin{tabular}{ccccc}
\hline NO & $\begin{array}{c}\text { Pendidila } \\
\boldsymbol{n}\end{array}$ & $\begin{array}{c}\text { Rentan } \\
\boldsymbol{g} \text { usia }\end{array}$ & $\begin{array}{c}\text { Frekuens } \\
\boldsymbol{i}(\boldsymbol{f})\end{array}$ & $\begin{array}{c}\text { Persentas } \\
\boldsymbol{e}(\boldsymbol{\%})\end{array}$ \\
\hline 1 & $\begin{array}{l}\text { Sekolah } \\
\text { dasar }\end{array}$ & $\begin{array}{l}11-12 \\
\text { tahun }\end{array}$ & 8 & 27 \\
2 & SMP & $\begin{array}{l}14 \\
\text { tahun } \\
16-19\end{array}$ & 7 & 23 \\
3 & SMA & $\begin{array}{l}16 \\
\text { tahun }\end{array}$ & & 50 \\
\hline \multicolumn{6}{c}{} & Jumlah & & $\mathbf{3 0}$ & $\mathbf{1 0 0}$ \\
\hline
\end{tabular}

Berdasarkan tabel 3 diatas dapat dilihat bahwa dari 30 responden yang berpendidikan sekolah dasar terdapat 8 (27\%)responden dengan rentang usia 11-12 tahun, berpendidikan SMP terdapat 7 (23\%)responden dengan rentang usia 14 tahun, berpendidikan SMA terdapat 15 (50\%) responden dengan rentang usia 16-19 tahun

Tabel 4. Distribusi frekuensi orang tua responden berdasarkan pekerjaan di remaja di RT 15 Sumberejo Kemiling Bandar lampung Tahun 2021

\begin{tabular}{llcc}
\hline NO & Pekerjaan & $\begin{array}{c}\text { Frekuensi }(\boldsymbol{f} \\
)\end{array}$ & $\begin{array}{c}\text { Persentase } \\
(\%)\end{array}$ \\
\hline 1 & Petani & 0 & 0 \\
2 & Wiraswata & 15 & 50 \\
3 & IRT & 0 & 0 \\
\hline
\end{tabular}




\begin{tabular}{llcc}
\hline 4 & Buruh & 6 & 20 \\
5 & PNS & 9 & 30 \\
\hline & Jumlah & $\mathbf{3 0}$ & $\mathbf{1 0 0}$ \\
\hline
\end{tabular}

Berdasarkan tabel 4.4 diatas dapat dilihat bahwa pekerjaan orang tua dari 30 responden yang berkerja sebagai petani $0(0 \%)$, berkerja sebagai wiraswasta $15(50 \%)$, berkerja sebagai ibu rumah tangga $0(0 \%)$, berkerja sebagai PNS 9 (30\%), berkerja sebagai buruh $6(20 \%)$, berkerja sebagai lain-lain $0(0 \%)$.

Tabel 5. Distribusi frekuensi responden berdasarkan suku remaja di RT 15 Sumberejo Kemiling Bandar Lampung Tahun 2021

\begin{tabular}{clcc}
\hline NO & Agama & $\begin{array}{c}\text { Frekuensi } \\
(\boldsymbol{F})\end{array}$ & Presentase(\%) \\
\hline 1 & Jawa & 23 & 77 \\
2 & Lampung & 3 & 10 \\
3 & Sunda & 0 & 0 \\
4 & Lain-lain & 4 & 13 \\
\hline & Jumlah & $\mathbf{3 0}$ & $\mathbf{1 0 0}$ \\
\hline
\end{tabular}

Berdasarkan tabel 5 di atas dapat dilihat bahwa dari 30 responden bersuku jawa 23 (77\%), bersuku lampung 3 (10\%), bersuku sunda $0(0 \%)$, bersuku lain-lain 4 (13\%).

Tabel 6. Distribusi frekuensi responden berdasarkan informasi remaja di RT 15 Sumberejo Kemiling Bandar Lampung Tahun 2021

\begin{tabular}{cccc}
\hline NO & Jenis usia & $\begin{array}{c}\text { Frekuensi } \\
(\boldsymbol{f})\end{array}$ & $\begin{array}{c}\text { Persentase } \\
(\boldsymbol{\%})\end{array}$ \\
\hline 1 & Sudah pernah & 22 & 73 \\
2 & Belum pernah & 8 & 27 \\
\hline & Jumlah & $\mathbf{3 0}$ & $\mathbf{1 0 0}$ \\
\hline
\end{tabular}

Berdasarkan tabel 6 diatas dapat dilihat bahwa dari 30 orang responden terdapat responden sudah pernah mendapatkan informasi tentang personal hygiene saat menstruasi terdapat $22(73 \%)$, responden belum pernah mendapatkan informasi tentang personal hygiene saat menstruasi terdapat 8 $(27 \%)$

\section{PEMBAHASAN}

\section{Hasil gambaran tingkat pengetahuan responden}

Hasil penelitian yang dilakukan pada 30 responden menunjukkan tingkat pengetahuan remaja usia 10-19 tahun tentang personal hygiene di RT 15 didapatkan hasil tingkat pengetahuan baik pada remaja sebanyak 12 (40\%) responden, tingkat pengetahuan cukup sebanyak 15 (50\%) responden dan tingkat pengetahuan kurang sebanyak 3 (10\%) responden. Fitriani (2015), tingkat pengetahuan dapat dipengaruhi oleh beberapa faktor seperti usia, pendidikan, pekerjaan orang tua, suku, dan informasi tentang personal hygiene saat menstruasi. Usia memiliki pengaruh dikarenakan seseorang yang berusia produktif pola pikirnya akan semakin berekembang. Tingkat pendidikan mempunyai pengaruh terhadap tingkat pengetahuan seseorang, semakin tinggi tingkat pendidikan semakin mudah pula seseorang menerima sebuah informasi. Pekerjaan membantu seseorang untuk mendapatkan sarana yang dapat menunjang proses belajar seseorang. Kebiasaan dan tradisi dapat berpengaruh untuk mendapatkan pengetahuan dan terhadap proses masuknya 
pengetahuan kedalam individu yang berada pada lingkungan tersebut. Informasi dapat menghasilkan perubahan dan memiliki tingkat pengetahuan yang tinggi. Hasil penelitian ini sesuai dengan penelitian yang di lakukan oleh Sih \& Maulina ( 2019), Pengetahuan remaja putri terhadap personal hygiene organ reproduksi di pondok pesantren babun najah ulee kareng kota banda aceh mendapatkan hasil yaitu sebanyak $24(57,1 \%)$ responden memiliki tingkat pengetahuan yang baik terhadap personal hygiene organ reproduksi dan sebanyak 18 responden $(42,9 \%)$ responden memiliki tingkat pengetahuan yang kurang baik terhadap personal hygiene organ reproduksi. Berdasarkan penelitian tersebut peneliti berharap kepada pelayanan kesehatan agar lebih meningkatkan penyuluhan terhadap remaja terkait pentingnya prilaku personal hygiene pada organ reproduksi sehingga terbebas dari adanya penyakit kelamin.

\section{Faktor yang mempengaruhi tingkat pengetahuan responden}

Berdasarkan tabel 1 diatas dapat dilihat bahwa dari 30 responden terdapat usia 10-13 tahun sejumlah 8 orang $(27 \%)$, responden yang berusia 14-19 tahun terdapat 22 orang (73\%). Responden di Rt 15 yang berusia 1419 tahun rata-rata memiliki tingkat pengetahuan yang baik hal ini dikarenakan seseorang yang berusia produktif pola pikirnya akan semakin berkembang hal tersebut sependapat dengan Fitriani (2015), Usia mempengaruhi daya tangkap dan pola pikir seseorang. Bertambahnya usia akan semakin berkembang pola pikir dan daya tangkap seseorang sehingga pengetahuan yang diperoleh akan semakin banyak.

Berdasarkan tabel 2 diatas dapat dilihat bahwa dari 30 responden yang berpendidikan sekolah dasar terdapat $8(27 \%)$ responden, berpendidikan SMP terdapat 7 (23\%) responden, berpendidikan SMA terdapat 15 (50\%) responden. Tingkat pengetahuan baik sebanyak 12 orang didapatkan dari SMA. Tingkat pendidikan mempunyai pengaruh terhadap tingkat pengetahuan seseorang, semakin tinggi tingkat pendidikan semakin mudah pula seseorang menerima sebuah informasi. Hal ini sesuai dengan pendapat dari Fitriani (2015), Pendidikan mempengaruhi proses belajar, semakin tinggi pendidikan seseorang akan mendapatkan informasi baik dari orang lain maupun media massa. Semakin banyak informasi yangmasuk, semakin banyak pula pengetahuan yang didapatkan tentang kesehatan.

Berdasarkan tabel 3 diatas dapat dilihat bahwa pekerjaan orang tua dari 30 responden yang berkerja sebagai petani $0(0 \%)$, berkerja sebagai wiraswasta $15 \quad(50 \%)$, berkerja sebagai ibu rumah tangga $0(0 \%)$, berkerja sebagai PNS 9 (30\%), berkerja sebagai buruh $6(20 \%)$, berkerja sebagai lain-lain $0(0 \%)$. 
Pekerjaan membantu seseorang untuk mendapatkan sarana yang dapat menunjang proses belajar seseorang. Hal ini sesuai dengan pendapat Fitriani (2015), Status ekonomi seseorang akan menentukan ketersediaan fasilitas yang diperlukan untuk kegiatan tertentu, sehingga status sosial ekonomi akan mempengaruhi pegetahuan seseorang. Pengetahuan dapat juga diperoleh dari pengalaman pribadi ataupun pengalaman orang lain.

Berdasarkan tabel 4 di atas dapat dilihat bahwa dari 30 responden bersuku jawa 23 (77\%), bersuku lampung 3 (10\%), bersuku sunda $0(0 \%)$, bersuku lain-lain $4(13 \%)$. Kebiasaan dan tradisi dapat berpengaruh untuk mendapatkan pengetahuan dan terhadap proses masuknya pengetahuan kedalam individu yang berada pada lingkungan tersebut. Hal ini sesuai dengan pendapat Fitriani (2015), Kebiasaan dan tradisi yang dilakukan seseorang tanpa melalui penalaran apakah yang dilakukan itu baik atau tidak. Lingkungan tempat tinggalnya berpengaruh terhadap proses masuknya pengetahuan kedalam individu yang berada pada lingkungan tersebut.

Berdasarkan tabel 4.6 diatas dapat dilihat bahwa dari 30 orang responden terdapat responden sudah pernah mendapatkan informasi tentang personal hygiene saat menstruasi terdapat $22(73 \%)$, responden belum pernah mendapatkan informasi tentang personal hygiene saat menstruasi terdapat 8 (27\%). Rata-rata responden sudah pernah mendapatkan informasi dari sekolah, sehingga dapat menghasilkan perubahan dan memiliki tingkat pengetahuan yang tinggi. Hal ini sesuai dengan pendapat Fitriani (2015), Informasi yang diperoleh baik pendidikan formal maupun non formal dapat memberikan pengetahuan jangka pendek (immediate impact), sehingga menghasilkan perubahan dan peningkatan pengetahuan. Kemajuan teknologi menyediakan bermacam-macam media massa yang dapat mempengaruhi pengetahuan masyarakat tentang informasi baru. Sarana komunikasi seperti televise, radio, surat kabar, majalah, penyuluhan dan lain lain mempunyai pengaruh besar terhadap pembentukan opini dan kepercayaan orang.

\section{KESIMPULAN}

Dari hasil penelitian tentang gambaran tingkat pengetahuan remaja usia 10-19 tahun tentang personal hygiene di RT 15 Sumberejo Kemiling Bandar Lampung Tahun 2021.Faktor yang mempengaruhi tingkat pengetahuan responden berdasarkan usia 1019 tahun, rata-rata usiaa responden yaitu berusia 14-19 tahun sejumlah 22 (73\%). Ratarata pendidikan yaitu SMA $15(50 \%)$. Ratarata pekerjaan orang tua yaitu wiraswasta 15 $(50 \%)$. Rata-rata suku responden yaitu bersuku jawa 23 (77\%). Rata-rata informasi 
responden yaitu sudah pernah mendapatkan informasi tentang personal hygiene saat menstruasi $21(70 \%)$.

Sebagian besar tingkat pengetahuan remaja usia 10-19 tahun tentang personal hygiene di RT 15 didapatkan hasil tingkat pengetahuan baik pada remaja sebanyak $12 \quad(40 \%)$ responden, tingkat pengetahuan cukup sebanyak $15(50 \%)$ responden, dan tingkat pengetahuan kurang sebanyak 3(10\%).

\section{KEPUSTAKAAN}

Agra, N. R. (2016). Gambaran pengetahuan remaja putri tentang remaja putri tentang personal hygiene saat menstruasi pada siswi sma negeri 1 sungguminasa tahun 2016. Diunduh dari http://repositori.uinalauddin. ac.id/5708/1/NUR\%20RAHMAWA TY\%20AGRA.PDF.padatanggal 14 februari 2021.

Alfianika, (2016).Pengaruh pendidikan kesehatan tentang personal hygiene dengan metode ceramah dan media audiovisual terhadap pengetahuan dan sikap remaja putri dalam mencegah keputihan dismk bakti purwokerto. Diunduh dari http:// repository.ump.ac.id/2707/3/Dody\% 20Yuli\%20Prakoso\%20BAB\%20II.p df. pada tanggal 6 mei 2021.
Anggito, A., \& Setiawan, J. (2018). Metodologi penelitian kualitatif. CV Jejak (Jejak Publisher)

Fitriani, (2015). Analisis pengetahuan siswa tentang makanan yang sehat dan bergizi terhadap pemilihan jajanan di sekolahan. Diunduh dari http:// epository.ump.ac.id/4114/3/Erlin \%20Yuliana_BAB\%20II.pdf. pada tanggal 2 maret 2021

Kumalasari, I \& Andhyantoro, I. (2016). Kesehatan reproduksi. Jakarta: Selemba Medika

Kusmiran, E. (2012). Kesehatan reproduksi remaja dan wanita. Jakarta: Selemba Medika

Nurmalasari, (2013). Metodologi penelitian ilmu keperawatan. Jakarta: Selemba Medika

Pythagoras, K. C. (2015). Personal hygiene remaja putri ketika menstruasi Diunduh dari http://ejurnal.unair .ac.id. pada tanggal 14 februari 2021.

Sih, P. K \& Maulina. (2019). Pengetahuan remaja putri terhadap personal hygiene organ reproduksi.Diunduh dari http://jim.unsyiah.ac.id/ FKep/article/download/12213/5365. pada tanggal 25 januari 2021

Yuni, N. E. (2015). Buku saku personal hygiene. Yogyakarta: Nuha Medika 